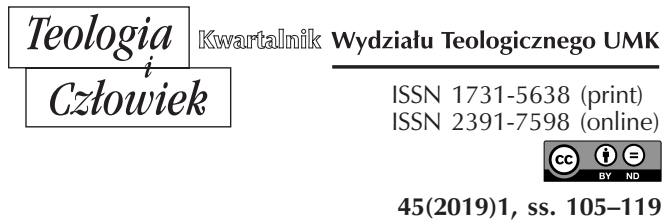

KS. TOMASZ WIELEBSKI

WYDZIAŁ TEOLOGICZNY UNIWERSYTETU KARDYNAŁA STEFANA WYSZYŃSKIEGO W WARSZAWIE

\title{
NAWRÓCENIE PASTORALNE I DUSZPASTERSTWO MISYJNE PARAFII W POLSCE
}

DOI: http://dx.doi.org/10.12775/TiCz.2019.006

Streszczenie. Papież Franciszek w adhortacji apostolskiej Evangelii gaudium realistycznie zauważył, że „wezwanie do rewizji i odnowy naszych parafii nie przyniosło jeszcze wystarczających owoców, aby były one bliżej ludzi i były środowiskami żywej komunii i uczestnictwa oraz ukierunkowały się całkowicie na misje" (EG 28). Odpowiadając na papieskie wezwanie kierowane do całego Kościoła o nawrócenie pastoralne i duszpasterstwo misyjne, autor artykułu próbuje spojrzeć na odnowę parafii w Polsce w kontekście kierunku wskazanego Kościołowi przez Franciszka, co wiąże się z rezygnacją z „wygodnego kryterium duszpasterskiego, że «zawsze się tak robiło»" (EG 33).

Prowadzone rozważania zawarto w czterech punktach. Po przedstawieniu teologicznej wizji parafii (1) ukazano istotę nawrócenia pastoralnego (2), którego owocem ma być duszpasterstwo misyjne (3). Przybliżenie nauczania Franciszka stało się punktem odniesienia do podjęcia refleksji na temat wytyczania kierunków pracy w polskich parafiach (4).

Słowa kluczowe: nawrócenie pastoralne; duszpasterstwo misyjne; parafie w Polsce.

Abstract. Pastoral Conversion and Missionary Ministry in the Polish Catholic Parishes. In his apostolic exhortation Evangelii gaudium Pope Francis has stated realistically that the call to review and renew our parishes has not yet sufficed to bring them nearer to people, to make them environments of living communion and participation, and 
to make them completely mission-oriented (EG 28). Answering this papal call directed to the whole Church and concerning the pastoral conversion and missionary ministry, the author of this article attempts to take a look at the renewal of the Catholic parishes in Poland in the context of the direction indicated by Pope Francis, which involves abandonment of the complacent attitude that says: "We have always done it this way" (EG 33).

The considerations carried out here consist of four parts. After presenting the theological vision of a Catholic parish (1), the authors moves on to emphasising the essence of the pastoral conversion (2), the culmination of which should be the missionary ministry (3). Visualising the teaching of Pope Francis became the point of giving consideration to the subject matter of setting the trends of working in the Polish parishes (4).

Key words: pastoral conversion; missionary ministry; Catholic parishes in Poland.

Papież Franciszek w adhortacji apostolskiej Evangelii gaudium realistycznie zauważył, że „wezwanie do rewizji i odnowy naszych parafii nie przyniosło jeszcze wystarczających owoców, aby były one bliżej ludzi i były środowiskami żywej komunii i uczestnictwa oraz ukierunkowały się całkowicie na misje" (EG 28). Warto w tym kontekście postawić pytanie dotyczące tego, co należy czynić, by tak dokonywać odnowy parafii, aby dobrze realizowały one swój główny cel, jakim jest urzeczywistnianie się Kościoła jako żywego Ludu Bożego ${ }^{1}$.

Mamy spojrzeć na odnowę parafii w kontekście kierunku wskazanego Kościołowi przez Franciszka, który wzywa do realizacji „duszpasterstwa misyjnego”, u źródeł którego leży „nawrócenie pastoralne”. Poznanie treści, które kryją się za tymi sformułowaniami pozwoli dobrze ukształtować naszą świadomość, a w perspektywie podjąć konkretne działania. Nie można zapominać o łączności między wymiarem normatywnym i duszpasterskim, na co też zwraca uwagę Franciszek, zaznaczając, że „teologia i duszpasterstwo idą w parze”2. Podkreśla on, że „doktryna teologiczna, która nie pozwala się ukierunkować i ukształtować przez

${ }^{1}$ R. Kamiński, Parafia miejscem duszpasterstwa, w: Teologia pastoralna szczegółowa, red. R. Kamiński, Lublin 2002, s. 12.

2 Franciszek, Przemówienie do członków papieskiego Instytutu Studiów nad Małżeństwem i Rodziną im. Jana Pawła II Piękno chrześcijańskiej rodziny (Watykan 27 X 2016), „L'Osservatore Romano” 2016, nr 11, s. 35. 
cel ewangelizacyjny, przez troskę duszpasterską Kościoła, jest tak samo nie do pomyślenia jak duszpasterstwo Kościoła, które nie potrafiłoby docenić Objawienia i jego tradycji w perspektywie lepszego zrozumienia i przekazywania wiary"3.

Nasze rozważania zostaną zawarte w czterech punktach. Po przedstawieniu teologicznej wizji parafii (1) zostanie ukazana istota nawrócenia pastoralnego (2), którego owocem ma być duszpasterstwo misyjne (3). Przybliżenie nauczania Franciszka ma być punktem odniesienia do podjęcia refleksji na temat wytyczania kierunków pracy w polskich parafiach (4).

\section{TEOLOGICZNA WIZJA PARAFII}

Teologiczna refleksja nad parafią zależy od sposobu rozumienia Kościoła, gdyż z perspektywy teologicznej nie posiada ona specyficznie własnego istnienia. O jej naturze teologicznej można mówić jedynie w relacji do Kościoła powszechnego i Kościoła lokalnego ${ }^{4}$. II Sobór Watykański, pogłębiając koncepcję Kościoła jako Ludu Bożego (KK 9-13), dowartościował zarazem problematykę Kościołów lokalnych, w których urzeczywistnia się Kościół powszechny. Z teologią Kościoła lokalnego wiąże się bardzo ściśle soborowe nauczanie o parafii, która jest nazywana „lokalną wspólnotą" (KK 28) i „komórką diecezji” (DA 10).

Soborowa wizja parafii jako wspólnoty znalazła swoje odzwierciedlenie w Kodeksie Prawa Kanonicznego z 1983 roku, który przedstawia parafię jako „określoną wspólnotę wiernych, utworzoną na sposób stały w Kościele partykularnym, nad którą pasterską pieczę, pod władzą biskupa diecezjalnego, powierza się proboszczowi jako jej własnemu pasterzowi”" (KPK 515 par. 1). Kodeksowe określenie istoty parafii zwraca uwagę na jej wymiar wspólnoty, odchodząc od wymiaru jurydycznego, akcentowanego przed II Soborem Watykańskim ${ }^{5}$.

3 Tamże.

${ }^{4}$ R. Kamiński, Parafia miejscem duszpasterstwa, s. 22.

${ }_{5}^{5}$ B. Biela, Pastoralne nawrócenie $w$ teorii i praktyce parafialnej, Katowice 2014, s. 27. 
Jan Paweł II, odwołując się do eklezjologii komunii (communio), która jest centralną i podstawową ideą w dokumentach Soboru ${ }^{6}$, podkreślił w adhortacji apostolskiej Christifideles laici, że:

parafia jest niejako ostatecznym umiejscowieniem Kościoła, a poniekąd samym Kościołem zamieszkującym pośród swych synów i córek. Wszyscy powinniśmy odkryć, przez wiarę, prawdziwe oblicze parafii, czyli samą „tajemnicę Kościoła”, który właśnie w niej istnieje i działa [...] Ona nigdy nie jest strukturą, terytorium, budynkiem, ale raczej „rodziną Bożą jako braci ożywionych duchem jedności” [KK 28]; „domem rodzinnym, braterskim i gościnnym", wspólnotą wiernych. [...] jest wspólnotą wiary oraz wspólnotą organiczną, czyli taką, która składa się z wyświęconych kapłanów i z innych chrześcijan (ChL 27).

Z kolei w liście na zakończenie wielkiego jubileuszu 2000 roku wzywał cały Kościół, aby stawał się „domem i szkołą komunii” (NMI 43), a wezwanie to należy też odnieść do każdej parafii, przez kontakt, z którą wielu ludzi buduje sobie obraz wspólnoty eklezjalnej.

Papież Franciszek spogląda na Kościół, w tym także na parafie, w duchu eklezjologii komunii, odwołując się przy tym do cytowanych już słów św. Jana Pawła II wzywających cały Kościół do tego, aby stawał się domem i szkołą komunii (NMI 43) ${ }^{7}$. Według Franciszka parafia, będąc „wspólnotą wspólnot, formą obecności Kościoła na danym terytorium, środowiskiem słuchania Słowa, wzrostu życia chrześcijańskiego, dialogu, przepowiadania, ofiarnej miłości, adoracji i celebracji, ma pobudzać i formować swoich członków, aby byli ludźmi ewangelizującymi” (EG 28). Według papieża „parafia nie jest muzeum pamięci o przeszłości lub symbolem obecności na terytorium, ale jest sercem misji Kościoła, gdzie przyjmujemy i dzielimy nowe życie"s.

${ }^{6}$ II Nadzwyczajne Zgromadzenie Generalne Synodu Biskupów. Relatio finalis. Kościót kierowany prze słowo Boże sprawuje tajemnice Chrystusa dla zbawienia świata, „L'Osservatore Romano” 1985, nr 10, s. 1-6 (dodatek).

7 Franciszek, Przemówienie do uczestników zgromadzenia ogólnego Ruchu Focolari - Dzieła Maryi Aby Kościół był domem i szkoła komunii (Watykan 26 IX 2014), „L'Osservatore Romano” 2014, nr 10, s. 36.

${ }^{8}$ Franciszek, Przemówienie podczas spotkania z Ukraińcami Codziennie pamiętam o Ukrainie (Watykan 28 I 2018), Ihttp://nowy.ekai.pl/media/szuflada/przemwienie_papiea_Franciszka [dostęp: 5.04.2018]. 


\section{NAWRÓCENIE PASTORALNE}

Określenie „nawrócenie pastoralne” pojawiło się w dokumencie podsumowującym V Ogólną Konferencję Episkopatów Ameryki Łacińskiej i Karaibów z maja 2007 roku, zwanym Dokumentem z Aparecidy ${ }^{9}$. Chociaż nie ma w nim podanej wprost definicji omawianego pojęcia, bo dokument ma charakter duszpasterski, nie będąc podręcznikiem teologicznym, to możemy odnaleźć w nim jego istotę: „nawrócenie pastoralne naszych wspólnot wymaga przejścia $\mathrm{z}$ duszpasterstwa jedynie zachowawczego do duszpasterstwa zdecydowanie misyjnego" (AP 370) ${ }^{10}$. Do tej myśli odniósł się Franciszek w Evangelii gaudium, apelując, aby „podążać drogą duszpasterskiego i misyjnego nawrócenia, które nie może pozostawić rzeczy w takim stanie, w jakim są" (EG 25).

Proces nawrócenia pastoralnego wiąże się z odkrywaniem i formowaniem tożsamości ucznia-misjonarza. Wspomniana tożsamość jest skutkiem sakramentu chrztu, na mocy którego każdy członek Ludu Bożego stał się uczniem-misjonarzem (Mt 28, 19), co czyni go aktywnym podmiotem ewangelizacji (EG 120).

Droga do odkrywania tożsamości ucznia-misjonarza jest procesem. Dokument $z$ Aparecidy w sposób systematyczny, a Evangelii gaudium pośredni, wymienia „pięć głównych aspektów formowania uczniów-misjonarzy". W różny sposób przejawiają się one na każdym z etapów drogi, uzupełniając się i czerpiąc z siebie nawzajem (AP 278). Do tych aspektów należą: spotkanie z Jezusem Chrystusem, nawrócenie, bycie uczniem, komunia, misja. Trzeba przy tym podkreślić, że proces nawrócenia pastoralnego, tak jak każdego nawrócenia, ma się dokonywać w nas przez cale życie, a więc także wtedy, kiedy realizujemy duszpasterstwo misyjne.

Początek narodzin ucznia-misjonarza jest związany ze „spotkaniem z Chrystusem”. Franciszek w Evangelii gaudium przywołuje słowa Benedykta z encykliki Deus Caritas est: „u początku bycia chrześcijaninem nie ma decyzji etycznej czy jakieś wielkiej idei, jest natomiast spotkanie z wydarzeniem, z Osobą, która nadaje życiu nową perspektywę, a tym samym

9 Zob. APARECIDA. V Ogólna Konferencja Episkopatów Ameryki Łacińskiej i Karaibów. Dokument końcowy Jesteśmy uczniami i misjonarzami Jezusa Chrystusa, aby nasze narody miały w nim życie, Gubin 2014 (dalej skrót AP).

${ }^{10}$ K. Kaproń, Kościót, który się nawraca, „Wieź” 4 (2013), s. 86. 
decydujące ukierunkowanie" (DCE 1; zob. AP 243). U źródeł spotkania z Jezusem Chrystusem leży doświadczenie mocy głoszonego kerygmatu. Następnym aspektem procesu formowania uczniów-misjonarzy jest „nawrócenie”. Dokument $z$ Aparecidy uczy, że jest ono pierwszą odpowiedzią tego, który słuchał Pana, „wierzy w Niego przez działania Ducha Świętego i decyduje się zostać Jego Przyjacielem iść za Nim, zmieniając swój sposób myślenia i życia, przyjmując krzyż Chrystusa ze świadomością, że umieranie dla grzechu jest zdobywanie życia” (AP 278).

Konsekwencją wcześniejszych etapów podjętej drogi jest „bycie uczniem". Chodzi tutaj o stałe wzrastanie w poznaniu, miłości i naśladowaniu Jezusa-Mistrza. W tym aspekcie procesu formacyjnego chrześcijanin poznaję głębiej osobę Jezusa. Fundamentalne znaczenie dla tego etapu ma katecheza i sakramenty, „które utwierdzają początkowe nawrócenie i pozwalają [...] trwać w chrześcijańskim nawróceniu i misji” (AP 278).

Czwartym elementem omawianego procesu jest „komunia - życie chrześcijańskie nie może istnieć poza wspólnotą: w rodzinach, w parafiach, we wspólnotach życia konsekrowanego, w eklezjalnych wspólnotach podstawowych oraz w innych małych wspólnotach i ruchach” (AP 278). Kolejnym etapem omawianego procesu jest „misja”. Dokument $z$ Aparecidy podkreśla, że uczeń, w miarę jak poznaje i miłuje Boga, „doświadcza potrzeby dzielenia się z innymi radością bycia posłanym, wyjścia do świata, aby głosić Jezusa Chrystusa” (AP 278). Dokument zauważa, „że misja jest nierozerwalnie związana z byciem uczniem" (AP 278). Kształtowanie się uczniów-misjonarzy ma prowadzić do tego, by Kościół, zachowując swoją tożsamość, stawał się jednocześnie w świecie zaczynem czyniącym ewangeliczny raban. Trzeba wstać z przysłowiowej kanapy, zamienić ją na parę butów i ruszyć na misję!. Według Franciszka nawrócenie pastoralne winno objąć każdy Kościół partykularny, czyli wszystkie diecezje, parafie i wspólnoty, co wymaga „wejścia w zdecydowany proces rozeznania, oczyszczenia i reformy" (EG 28-30). Franciszek nieustannie podkreśla, że nawrócenie pastoralne wiąże się miedzy innymi z koniecznością reform struktur, które mają stać się bardziej misyjne, „by duszpasterstwo zwyczajne we wszystkich swoich formach było bardziej ekspansywne i otwarte, by doprowadziło pracujących $\mathrm{w}$ duszpasterstwie do przyjmowania postawy "wyjścia«" (EG 27). 


\section{DUSZPASTERSTWO MISYJNE}

Skutkiem nawrócenia pastoralnego ma być duszpasterstwo realizowane w kluczu misyjnym, które „wymaga rezygnacji z wygodnego kryterium duszpasterskiego, że «zawsze się tak robiło»" (EG 33). Papież ze smutkiem zauważa, że mało gościnne struktury parafii i wspólnot, biurokratyczne podejście do zwykłych i złożonych problemów ludzi oraz panujący w nich klimat sprawia, że część osób ochrzczonych nie doświadcza swojej przynależności do Kościoła (EG 63). Zwraca też uwagę na to, że w wielu miejscach „aspekt administracyjny bierze górę nad aspektem duszpasterskim" oraz zauważa, że pojawia się sakramentalizacja bez innych form ewangelizacji (EG 63).

Jakie są cechy charakterystyczne, pewne kryteria, do których odniesienie może pomóc w szukaniu odpowiedzi na pytanie dotyczące tego, czy prowadzone w parafii działania duszpasterskie możemy określać jako duszpasterstwo misyjne? Wśród tych kryteriów trzeba szczególnie zwrócić uwagę na misyjność i postawę wyjścia, macierzyńskość związaną z bliskością i spotkaniem, właściwie rozumiany pluralizm duszpasterski.

Według Franciszka misyjność duszpasterstwa jest uwarunkowana koniecznością reformy struktur kościelnych, zwyczajów, stylów działania, rozkładu zajęć, co sprawi, że duszpasterstwo stanie się ekspansywne i otwarte, związane z przyjmowaniem postawy wyjścia (EG 27). Podkreśla on, że chrześcijanie tworzący Kościół nie mogą być ludźmi zamykającymi się w parafii, w ruchu, kręgu przyjaciół i osób myślących podobnie jak oni, ale mają być Kościołem wychodzącym poza siebie, w stronę „peryferii egzystencji”. Takimi peryferiami są miejsca, w których nie ma Boga i obszary, którym zagraża marginalizacja - gdzie znajdują się ludzie zepchnięci na margines i pogardzani przez innych ${ }^{11}$. Mówiąc o misyjnym wyjściu Kościoła, Franciszek szczególną uwagę zwraca na tych, którzy będąc na peryferiach egzystencji, zwykle nie przychodzą do parafii. Wspomniane osoby są zaproszonymi VIP-ami, których mamy szukać na obrzeżach

${ }^{11}$ Franciszek, Przemówienie podczas spotkania z księżmi, zakonnikami i zakonnicami Kościół wzrasta dzięki atrakcyjności świadectwa (Asyż 4 X 2013), 14-15. 
dróg ${ }^{12}$. Nawiązując do opisu ukazującego wędrówkę uczniów do Emaus (Łk 24, 13-15), papież zwraca uwagę na to, że w dzisiejszych czasach jest dużo ludzi przypominających tamtych uczniów. Dla niektórych z nich Kościół jawi się daleki od ich potrzeb, jest zimny, zbyt skoncentrowany na sobie, nie odpowiadający na nowe pytania, używający zbyt surowego języka. Według Franciszka Kościół powinien „wejść w ich noc, prowadzić $\mathrm{z}$ nimi rozmowę i dialog oraz [...] towarzyszyć w drodze powrotnej do domu"13.

Do kogo w sposób szczególny ma wyjść Kościół? Nieustannie w nauczaniu Franciszka pojawia się postulat wyjścia do ludzi przeżywających wielorakie ubóstwo, bo oni są uprzywilejowanymi adresatami Ewangelii (EG 48). Franciszek wyróżnia dawne i nowe formy ubóstwa, mówiąc o bezrobociu, emigracji, różnego rodzaju uzależnieniach ${ }^{14}$. Wyjście Kościoła na zewnątrz, szczególnie wobec ludzi ubogich, wiąże się z budowaniem kultury spotkania, którą Franciszek nazywa kultura przyjaźni związaną z rozmową z tymi, którzy nie myślą tak jak my, pamiętając o zachowaniu własnej tożsamości ${ }^{15}$. Franciszek, zauważając, że „główną belką, na której wspiera się życie Kościoła jest miłosierdzie”, z naciskiem podkreśla, że wszystko w działaniu duszpasterskim „powinno zostać otulone czułością, z jaką kieruje się do wiernych" ${ }^{16}$. Według papieża „wiarygodność Kościoła weryfikuje się na drodze miłości miłosiernej i współczującej”'17.

Franciszek wskazuje na ścisły związek duszpasterstwa z „macierzyństwem”. Duszpasterstwo jest realizowaniem macierzyństwa Kościoła

12 Franciszek, Homilia podczas mszy św. biskupów, kapłanów, zakonników, zakonnic i seminarzystów Idźmy na rozstaje dróg (Rio de Janeiro 27 VII 2013), „L'Osservatore Romano" 2013, nr 10, s. 18.

${ }^{13}$ Franciszek, Przemówienie podczas spotkania z episkopatem Brazylii Duszpasterstwo to realizowanie macierzyństwa Kościoła (Rio de Janeiro 27 VII 2013), „L’Osservatore Romano" 2013, nr 10, s. 21-22.

${ }_{14}$ Franciszek, Orędzie na 29. Światowy Dzień Młodzieży Zarażanie radością (Watykan 21 I 2014), „L'Osservatore Romano” 2014, nr 2, s. 12.

15 Franciszek, Przemówienie podczas czuwania modlitewnego z okazji dnia ruchów, nowych wspólnot i stowarzyszeń kościelnych Kościót wychodzi naprzeciw wszystkim (Watykan 18 V 2013), „L'Osservatore Romano” 2013, nr 7, s. 19.

${ }_{16}$ Franciszek, Bulla Misericordiae vultus, Watykan 2015, nr 10.

17 Tamże. 
rodzącego, karmiącego, wychowującego, korygującego, prowadzącego za rękę. Ma on ciągle odkrywać swoje macierzyńskie miłosierdzie, bo bez tego nie wejdzie w świat ludzi poranionych, potrzebujących zrozumienia, przebaczenia i miłości ${ }^{18}$. Mówiąc o macierzyńskości duszpasterstwa, trzeba podkreślić, że Franciszek, odwołując się do Dokumentu z Aparecidy, mówi o konieczności zwracania uwagi na dwie, wynikające z oryginalności samej Ewangelii, kategorie duszpasterskie. Są one zarazem kryterium oceny życia eklezjalnego uczniów i misjonarzy - to „bliskość” i „spotkanie”19. Odpowiadając na pytanie jednego z biskupów podczas spotkania na Wawelu 27 lipca 2017 roku, Franciszek zwrócił uwagę na parafię, która musi być parafią $z$ otwartymi drzwiami, wychodzącą i szukającą wszystkich ludzi ${ }^{20}$. Papież przestrzega przed duszpasterstwami odległymi i dyscyplinarnymi, przywiązującymi wielką uwagę do pewnych zasad i procedur organizacyjnych, ale pozbawionymi bliskości, czułości i serdeczności. Podkreśla, że są to „duszpasterstwa dobrze zaprogramowane z tak wielką dozą dystansu, że nie mogą doprowadzić do spotkania z Jezusem i braćmi”21. Według Franciszka w procesie ewangelizowania wszystkich środowisk i dziedzin życia oraz odnowy Kościoła ważną rolę odgrywają wszystkie wspólnoty podstawowe, małe wspólnoty, ruchy oraz inne formy stowarzyszeń, które pobudzone przez Ducha, nie mogą utracić kontaktu z rzeczywistością parafialną, przekształcając się w „koczowników pozbawionych korzeni” (EG 29). Ich członkowie nie mają się hermetycznie zamykać we własnym kręgu ani w parafii, ale, nie rezygnując ze swojej tożsamości, wychodzić naprzeciwko wszystkim ludziom, budując kulturę spotkania ${ }^{22}$.

18 Franciszek, Przemówienie podczas spotkania z episkopatem Brazylii Duszpasterstwo to realizowanie macierzyństwa Kościoła (Rio de Janeiro 27 VII 2013), s. 23.

19 Franciszek, Przemówienie podczas spotkania z członkami komitetu koordynacyjnego CELAM Nie należy ignorować „rewolucji czułości”, która spowodowała wcielenie Słowa (Rio de Janerio 28 VII 2013), s. 28.

20 Tamże, s. 10.

${ }^{21}$ Franciszek, Przemówienie podczas spotkania z członkami komitetu koordynacyjnego CELAM Nie należy ignorować „rewolucji czułości”, która spowodowała wcielenie Słowa (Rio de Janerio 28 VII 2013), s. 28

${ }^{22}$ Franciszek, Przemówienie podczas czuwania modlitewnego z okazji dnia ruchów, nowych wspólnot i stowarzyszeń kościelnych Kościół wychodzi naprzeciw wszystkim (Watykan 18 V 2013), 18-19. 


\section{KU PRZYSZKOŚCI POLSKICH PARAFII}

Po przedstawieniu teologicznej wizji parafii oraz wybranych elementów nauczania Franciszka dotyczących nawrócenia pastoralnego i duszpasterstwa misyjnego, warto postawiać pytania dotyczące tego, jak można je odnieść do polskich parafii. Nie sposób w tego typu opracowaniu podać całościowej i wyczerpującej strategii działań, można jedynie zasygnalizować pewne obszary, w kierunku których powinny podążać polskie parafie.

Jednym z podstawowych pytań, na które należy szukać odpowiedzi, jest pytanie o teologiczną wizję parafii, którą noszą w sobie zarówno duchowni, jak i świeccy. Musi ona być zgodna z nauczaniem II Soboru Watykańskiego podkreślającego obraz Kościoła jako communio. W tym kontekście trzeba zaznaczyć, że aktualne jest przesłanie zawarte w dokumentach II Polskiego Synodu Plenarnego, mówiących o tym, iż „należy usilnie starać się o kształtowanie modelu parafii jako wspólnoty wspólnot ${ }^{23}$. Pomimo tego, że od zakończenia II Polskiego Synodu Plenarnego minęło już dwadzieścia lat, wiele wspólnot parafialnych jeszcze nie przeprowadziło rachunku sumienia, do którego wzywał Synod. Pojawiły się w nim pytania, z których w sposób szczególny trzeba zwrócić uwagę na jedno: „czy nasza parafia, to piramida - hierarchiczna organizacja, na czele której stoi proboszcz, myślący, decydujący i pracujący za wszystkich, czy też wspólnota wspólnot skoncentrowanych wokół duszpasterza, będącego jej animatorem?"24.

Nawrócenie pastoralne i duszpasterstwo misyjne Kościoła w Polsce wymaga $\mathrm{w}$ wielu sytuacjach zmiany sposobu funkcjonowania parafii. Trzeba stawiać sobie pytanie, czy struktury parafii dobrze służą misyjnemu przeobrażeniu Kościoła ${ }^{25}$. Nie wolno uciekać przed ich reformą, zwracając uwagę na to, że istnieją takie, „które mogą doprowadzić do krępowania dynamizmu ewangelizacyjnego" (EG 26).

${ }^{23}$ Potrzeby i zadania nowej ewangelizacji na przełomie II i III Tysiaclecia Chrześcijaństwa, w: II Polski Synod Plenarny (1991-1999), Poznań-Warszawa 2001, nr 43, s. 22.

${ }^{24}$ Tamże.

25 Z. Nosowski, Nawrócenie kościelnych struktur, http://wiez.com.pl/2018/01/07/ nawrocenie-koscielnych-struktur [dostęp: 4.12.2018]. 
Ważną kwestią pozostaje model czy też typ funkcjonowania parafii, który jest kształtowany przez sposób jej rozumienia, budowania wspólnoty, kierowania nią, relacji między duchowieństwem i wiernymi świeckimi. Trudno jest wskazać na uniwersalny model parafii, gdyż jest on zawsze uwarunkowany określonymi warunkami historyczno-społecznymi i kulturowymi. Z prowadzonych w Polsce badań wynika, że w polskim duszpasterstwie dominują zasadnicze dwa typy parafii: hierarchiczny oraz organizacyjny ${ }^{26}$. Typ hierarchiczny występuje wtedy, gdy parafia jest rozumiana tylko jako instytucja ściśle przyporządkowana hierarchicznej strukturze Kościoła. Głównym podmiotem takiej parafii jest proboszcz, a wierni stanowią przedmiot jego duszpasterskiej troski.. Parafia żyjąca takim modelem duszpasterstwa zabiega przede wszystkim o zachowanie tradycji kultycznych realizowanych w obrębie świątyni ${ }^{27}$. Z kolei w parafii realizującej model organizacyjny „organizuje” ona propozycje duszpasterskie dla wiernych, pewne „akcje” kierowane dla poszczególnych grup parafian, nie dopuszczając nikogo do czynnego udziału w procesie rozeznania potrzeb, a następnie w ich realizacji. W parafii działającej według takiego modelu duszpasterstwo jest organizowane „dla”, a nie „z, z autorytatywnym rozstrzygnięciem, kto czego w parafii potrzebuje ${ }^{28}$. Trzeba zauważyć, że w polskiej rzeczywistości parafialnej z trudem przebija się idea przekształcania parafii we wspólnotę, postulowaną w Magisterium. Potrzeba podjęcia trudu przekształcania polskich parafii we wspólnotę wspólnot, odznaczającą się bliskością, niezbiurokratyzowaną, z którą parafianie będą czuli się związani, podejmując współodpowiedzialności za tworzenie jej kształtu.

Odnowa polskich parafii powinna odznaczać się dostosowywaniem swoich struktur i sposobów działania do wymogów eklezjologii komunii. Wiąże się to zarówno z koniecznością formowania i odpowiedniego przygotowywania wiernych świeckich, uczniów-misjonarzy, do przyjmowania postawy wyjścia, jak też do przyjęcia realizowanych w części parafii projektów odnowy i budowania parafii, zmierzających do kształtowania ich w duchu Kościoła communio. Proponowane rozwiązania mają wspólne

${ }^{26}$ B. Biela, Pastoralne nawrócenie $w$ teorii i praktyce parafialnej, s. 63.

27 A. Żądło, Parafia $w$ trzecim tysiącleciu, Kielce 1999, s. 42-43.

28 B. Biela, Pastoralne nawrócenie $w$ teorii i praktyce parafialnej, s. 63. 
założenia i cele, zmierzające do realizacji nawrócenia duszpasterskiego. Należą do nich projekty: „Nowy Obraz Parafii” "29, „System ewangelizacyjnych komórek parafialnych”30 „Parafia wspólnotą wspólnot”31. Parafie mogą również skonstruować swój projekt odnowy, korzystając z różnych polskich $^{32}$ czy zagranicznych doświadczeńn ${ }^{33}$.

Ważną kwestią jest dotarcie z przesłaniem Ewangelii do osób niechodzących systematycznie do kościoła albo w ogóle niepraktykujących. W tym celu należy pomyśleć o ewangelizacji ulicznej w parafii, w tym też o docieraniu do mieszkańców parafii metodą „od drzwi do drzwi”. Ewangelizacja uliczna może przejawiać się w prowadzeniu indywidualnych rozmów ze spotykanymi osobami, koncertami, publicznym składaniem świadectwa, odgrywaniem pantomimy. Takie niekonwencjonalne sposoby prowadzenia ewangelizacji przez merytorycznie i duchowo przygotowanych świeckich ewangelizatorów są dobrą okazją do głoszenia kerygmatu i zaproszenia spotkanych osób na rekolekcje ewangelizacyjne do parafii.

W powyższe działania w sposób szczególny należy angażować członków różnych grup i wspólnot. W świetle badań pokazujących, że około 2,5 miliona osób jest członkami różnych stowarzyszeń i grup apostolskich $^{34}$, wydaje się, że jest to jeszcze niewykorzystany potencjał „śpiącego olbrzyma”. Czy część z nich nie zamykają się w swoim kręgu, nie podejmując działań ewangelizacyjnych skierowanych do osób będących na kościelnych peryferiach? Czy nieraz też nie zauważa się wśród ich członków pewnego izolacjonizmu od spraw lokalnej parafii? Może w niewystarczający sposób w prowadzonej formacji zwraca się na konieczność ich związku z parafią, która ma być ich podstawowym miejscem urzeczy-

${ }^{29}$ M. Nowak, O nowa wizje parafii, Warszawa 1994.

30 G. Macchioni, Ewangelizacja w parafii. Metoda komórek, Kraków 1997.

31 A. Falicco, Projekt parafii jako wspólnoty wspólnot, Kielce 1995.

32 L. Slipek, Parafia jakiej pragnę, Warszawa 2001; tenże, Parafia $w$ wielkim mieście, Warszawa 2009.

${ }_{33}$ M. White, T. Corcoran, Historia katolickiej parafi. Odbudowana czyli jak przebudzić wiernych, dotrzeć do zagubionych i nadać Kościołowi znaczenie, Gubin 2013.

${ }^{34}$ A. Petrowa-Wasilewicz, Świeccy w Kościele - przebudzenie olbrzyma, Internetowy Dziennik Katolicki. Serwis Informacyjny Kai, 4 XII 2018, http://nowy.ekai.pl/ media/szuflada/Dziaalno_charytatywna_Kocioa_katolickiego_w_Polsce_.htm [dostęp: 20.12.2018]. 
wistniania się, „a ich działanie powinno mieć na celu ożywienie struktury parafialnej tak, by przesunąć akcenty z instytucji na wspólnotę"35.

Ważną kwestią w parafii jest podejmowanie działalności charytatywnej, zaradzającej wielorakim obszarom ubóstwa, zarówno materialnego, jak i duchowego. W każdej parafii powinny funkcjonować Parafialne Zespoły Caritas, aby współpracując z Parafialnymi Radami Duszpasterskimi najpierw dokonać właściwej diagnozy różnych przestrzeni ubóstwa, a następnie zastanowić się, jak skutecznie nieść pomoc, podejmując próby systemowego rozwiązywania różnych problemów.

Ks. Franciszek Blachnicki napisał, że „odnowa soborowa tak długo będzie fikcją, jak długo nie zejdzie na płaszczyznę parafii, jak długo nie wypracujemy modelu posoborowego duszpasterstwa parafialnego"36. Warto zestawiać powyższe słowa $\mathrm{z}$ nauczaniem papieża Franciszka dotyczącym wezwania do nawrócenia pastoralnego i duszpasterstwa misyjnego. Są one ciągłym nawoływaniem do przełamywania pewnych schematów działań w polskich parafiach. Związane jest to jest ze zmianą sposobów myślenia, co ma być owocem nawrócenia pastoralnego. Podejmując różnego rodzaju działania, nie ulegnijmy pokusie aktywizmu, nie zapominajmy o modlitwie, która powinna poprzedzać każde działanie duszpasterskie. Warto w tym kontekście przywołać nauczanie Franciszka, który dał przestrogę, aby nie podążać

za głosem syren, które nawołują do tego, aby z duszpasterstwa uczynić serię gorączkowych inicjatyw, nie umiejąc uchwycić tego, co istotne w pracy ewangelizacyjnej. Niekiedy wydaje się nam, że bardziej zabiegamy o mnożenie form działania zamiast zatroszczyć się o osoby i ich spotkanie z Bogiem [...] Duszpasterstwo bez modlitwy i kontemplacji nie będzie mogło nigdy dotrzeć serca osób. Pozostanie na powierzchni, nie pozwalając ziarnu słowa Bożego zakorzenić się, wykiełkować, wzrastać i wydać owoc (por. Mt 13, 1-23) 37 .

${ }^{35}$ W. Śmigiel, Eklezjalność zrzeszeń religijnych, Pelplin 2015, s. 180.

36 F. Blachnicki, Oaza Rekolekcyjna Diakonii Ruchu Światło-Życie, bmw 1995, s. 146 .

37 Franciszek, Przemówienie do biskupów uczestniczących w seminarium zorganizowanym przez Kongregację ds. Ewangelizacji Narodów Nawrócenie misyjne Kościoła (Watykan 20 IX 2014), „L'Osservatore Romano” 2014, nr 10, s. 33. 


\section{BIBLIOGRAFIA}

APARECIDA. V Ogólna Konferencja Episkopatów Ameryki Łacińskiej i Karaibów. Dokument końcowy Jesteśmy uczniami i misjonarzami Jezusa Chrystusa, aby nasze narody miały w nim życie, Gubin 2014

Biela B., Pastoralne nawrócenie w teorii i praktyce parafialnej, Katowice 2014.

Blachnicki F., Oaza Rekolekcyjna Diakonii Ruchu Światło-Życie, bmw 1995, s. 146.

II Nadzwyczajne Zgromadzenie Generalne Synodu Biskupów. Relatio finalis. Kościół kierowany przez słowo Boże sprawuje tajemnice Chrystusa dla zbawienia świata, „L'Osservatore Romano” 1985, nr 10, s. 1-6 (dodatek).

Franciszek, Adhortacja Evangelii gaudium, Watykan 2013.

Franciszek, Przemówienie podczas spotkania z dziennikarzami Kościół ubogi i dla ubogich (Watykan 16 III 2013), „L'Osservatore Romano” 2013, nr 5, s. 12-13.

Franciszek, Przemówienie podczas czuwania modlitewnego z okazji dnia ruchów, nowych wspólnot i stowarzyszeń kościelnych Kościół wychodzi naprzeciw wszystkim (Watykan 18 V 2013), „L'Osservatore Romano” 2013, nr 7, s. 16-20.

Franciszek, Przemówienie podczas spotkania z młodzieżą argentyńską Niech was będzie stychać (Rio de Janeiro 25 VII 2013), „L'Osservatore Romano” 2013, nr 8-9, s. 8-9.

Franciszek, Homilia podczas mszy św. biskupów, kapłanów, zakonników, zakonnic i seminarzystów Idźmy na rozstaje dróg (Rio de Janeiro 27 VII 2013), „L'Osservatore Romano" 2013, nr 10, s. 17-18.

Franciszek, Przemówienie podczas spotkania z episkopatem Brazylii Duszpasterstwo to realizowanie macierzyństwa Kościoła (Rio de Janeiro 27 VII 2013), „L’Osservatore Romano" 2013, nr 10, s. 19-24.

Franciszek, Przemówienie podczas spotkania z członkami komitetu koordynującego CELAM Nie należy ignorować „rewolucji czułości”, która spowodowała wcielenie Słowa (Rio de Janerio 28 VII 2013), „L'Osservatore Romano” 2013, nr 10, s. 25-29.

Franciszek, Homilia podczas mszy św. w czasie wizytacji rzymskiej parafii św. Cyryla Aleksandryjskiego Życie chrześcijańskie jest droga (Rzym 1 XII 2013), „L'Osservatore Romano" 2014, nr 1, s. 13-14.

Franciszek, Orędzie na 29. Światowy Dzień Młodzieży Zarażanie radością (Watykan 21 I 2014), „L'Osservatore Romano” 2014, nr 2, s. 10-13.

Franciszek, Przemówienie podczas spotkania z kapłanami Czy pracujemy jak dobrzy robotnicy? (Cassano all'Ionio 21 VI 2014), „L'Osservatore Romano” 2014, nr 7, s. $44-45$.

Franciszek, Przemówienie do biskupów uczestniczących w seminarium zorganizowanym przez Kongregację ds. Ewangelizacji Narodów Nawrócenie misyjne Kościoła (Watykan 20 IX 2014), „L'Osservatore Romano” 2014, nr 10, s. 33-34.

Franciszek, Przemówienie do uczestników zgromadzenia ogólnego Ruchu Focolari Dzieła Maryi Aby Kościół był domem i szkoła komunii (Watykan 26 IX 2014), „L'Osservatore Romano” 2014, nr 10, s. 35-36.

Franciszek, Bulla Misericordiae vultus, Watykan 2015. 
Franciszek, Orędzie na 50. Światowy Dzień Modlitw o Powołania Wyjście jako fundamentalne doświadczenie powołania (Watykan 29 III 2015), „L'Osservatore Romano” 2015, nr 5, s. 16-17.

Franciszek, Przemówienie podczas spotkania z biskupami meksykańskimi $Z$ proroczq odwaga (Meksyk 13 II 2016), „L'Osservatore Romano” 2016, nr 3-4, s. 21-27.

Franciszek, Rozmowa z polskimi biskupami w katedrze na Wawelu Ewangelia bliskości, (Kraków 27 VII 2016), „L’Osservatore Romano” 2016, nr 7-8, s. 6-11.

Franciszek, Przemówienie podczas czuwania modlitewnego z młodzieżą na Campus Misericordiae Nic nie usprawiedliwia przelewu bratniej krwi (Kraków 30 VII 2016), „L'Osservatore Romano” 2016, nr 7-8, s. 25-27.

Franciszek, Przemówienie do członków papieskiego Instytutu Studiów nad Małżeństwem i Rodziną im. Jana Pawła II Piękno chrześcijańskiej rodziny (Watykan 27 X 2016), „L'Osservatore Romano” 2016, nr 11, s. 33-35.

Franciszek, Przemówienie podczas spotkania z Ukraińcami Codziennie pamiętam o Ukrainie (Watykan 28 I 2018), Ihttp://nowy.ekai.pl/media/szuflada/przemwienie_papiea_Franciszka [dostęp: 5.04.2018].

Gądecki S., Słowo wstępne, w: Komisja Duszpasterstwa Konferencji Episkopatu Polski, Wierze w Syna Bożego. Przez Chrystusa, z Chrystusem, w Chrystusie. Przez wiarę i chrzest do świadectwa. Program duszpasterski Kościoła w Polsce na lata 2013-2017, Poznań 2013, s. 9-16.

GUS, 81\% Polaków deklaruje się jako wierzacy, Internetowy Dziennik Katolicki. Serwis Informacyjny KAI, 21 XII 2018, http://nowy.ekai.pl/media/szuflada/GUS_htm [dostęp: 21.12.2018].

Kamiński R., Parafia miejscem duszpasterstwa, w: Teologia pastoralna szczegółowa, red. R. Kamiński, Lublin 2002, s. 11-78.

Kaproń K., Kościót, który się nawraca, „Wieź” 4 (2013), s. 84-90.

Nosowski Z., Nawrócenie kościelnych struktur, http://wiez.com.pl/2018/01/07/nawrocenie-koscielnych-struktur [dostęp: 4.12.2018].

Petrowa-Wasilewicz A., Świeccy w Kościele - przebudzenie olbrzyma, Internetowy Dziennik Katolicki. Serwis Informacyjny KAI, 4 XII 2018, http://nowy.ekai.pl/media/ szuflada/Dziaalno_charytatywna_Kocioa_katolickiego_w_Polsce_.htm [dostęp: 20.12.2018].

Przeciszewski M., Działalność charytatywna Kościoła w Polsce, Internetowy Dziennik Katolicki. Serwis Informacyjny KAI, 4 XII 2018, http://nowy.ekai.pl/media/ szuflada/Dziaalno_charytatywna_Kocioa_katolickiego_w_Polsce_.htm [dostęp: 20.12.2018].

Potrzeby i zadania nowej ewangelizacji na przełomie II i III Tysiaclecia Chrześcijaństwa, w: II Polski Synod Plenarny (1991-1999), Poznań-Warszawa 2001, s. 9-28.

Sadłoń W., Duszpasterskie Rady w Polsce na podstawie badań empirycznych, „Teologia Praktyczna” 14:2013, s. 73-90 (DOI: https://doi.org/10.14746/tp.2013.14.06).

Śmigiel W., Eklezjalność zrzeszeń religijnych, Pelplin 2015.

Żądło A., Parafia w trzecim tysiącleciu, Kielce 1999. 